\title{
Chapter 11 \\ Gene Delivery and Expression Systems in Induced Pluripotent Stem Cells
}

\author{
Maolin Zhang, Kunimichi Niibe, Takeru Kondo, Yuya Kamano, \\ Makio Saeki, and Hiroshi Egusa
}

\begin{abstract}
Induced pluripotent stem (iPS) cells, which can be generated from somatic cells by genetic manipulation, are invaluable experimental and therapeutic tools for development of tissue regeneration technologies. Many studies have demonstrated that gene delivery to pluripotent stem cells is useful for basic studies in developmental biology and for driving differentiation toward a specific cell lineage for regenerative applications. Several gene delivery systems using viral and nonviral vectors have been used for stem cell research. These gene delivery systems are designed to accommodate specific research purposes; thus, each of them possesses its own advantages and disadvantages according to the experimental design. In addition, the type of constitutive promoter in the expression vector greatly affects the transcriptional activity of transgenes in pluripotent stem cells. Therefore, it is necessary to consider the characteristics of the vectors and their promoters when selecting a gene delivery system to transfer the target gene into iPS cells. In this mini-review, characteristics of commonly used viral (adenoviral, adeno-associated viral, retroviral, and lentiviral) vectors and a nonviral piggyBac transposon DNA vector with constitutive promoters are outlined to support the selection of an appropriate gene delivery and expression system for iPS cell research.
\end{abstract}

M. Zhang • K. Niibe • T. Kondo • Y. Kamano

Division of Molecular and Regenerative Prosthodontics, Tohoku University Graduate School of Dentistry, 4-1 Seiryo-machi, Aoba-ku, Sendai, Miyagi 980-8575, Japan

M. Saeki

Division of Dental Pharmacology, Niigata University Graduate School of Medical and Dental Sciences, Niigata, Japan

H. Egusa $(\bowtie)$

Division of Molecular and Regenerative Prosthodontics, Tohoku University Graduate School of Dentistry, 4-1 Seiryo-machi, Aoba-ku, Sendai, Miyagi 980-8575, Japan

Center for Advanced Stem Cell and Regenerative Research, Tohoku University Graduate School of Dentistry, Sendai, Miyagi, Japan

e-mail: egu@dent.tohoku.ac.jp 
Keywords Constitutive promoter $\bullet$ Induced pluripotent stem (iPS) cells $\bullet$ PiggyBac transposon-based gene delivery $\bullet$ Tetracycline-controlled transcriptional regulation - Viral vector

\subsection{Introduction}

Stem cells, which are characterized as immature, self-renewal, and undifferentiated cells that can give rise to many different cell lineages, are expected to open new needed therapeutic avenues [1]. Induced pluripotent stem (iPS) cells are cells reprogrammed from somatic cells via genetic modification to obtain embryonic stem (ES) cell characteristics [2,3]. Although multipotent adult stem cells such as mesenchymal stem cells (MSCs) have been well investigated for clinical application [4], basic research on pluripotent stem cells, such as ES cells and iPS cells, may lead to further understanding of in vitro tissue/organ development, which in turn could be applied to next-generation therapeutic approaches for whole-tissue/organ regeneration.

Gene delivery to pluripotent stem cells provides a powerful experimental system to investigate the early stages of tissue/organ development. In addition, genetic modification of patient-specific iPS cells, particularly disease-model iPS cells, could facilitate the study of pathological mechanisms and provide new therapeutic approaches in personalized medicine [5]. To obtain efficient and stable transgene expression, various gene delivery methods ranging from viral vectors to plasmidbased transient gene expression have been applied to pluripotent stem cells [6]. In these methods, many types of constitutive promoters have been utilized in the expression vectors, such as the cytomegalovirus (CMV), human elongation factor $1 \alpha(\mathrm{EF} 1 \alpha), \mathrm{CMV}$ enhancer/ $\beta$-actin promoter with $\beta$-actin intron (CA), Rous sarcoma virus (RSV) [7], human $\beta$-actin (ACTB), phosphoglycerate kinase (PGK) [8], and simian virus 40 early (SV40) [9] promoters. The transcriptional activity of transgenes considerably varies among these promoters depending on the cell type [10]. Notably, the CMV promoter, which is one of the most popular choices for gene delivery vectors because of its strong activity in most cell lines, shows considerably weak transgene activation in stem cells [7, 8, 11-14]; therefore, it is important to select an optimal promoter to obtain the expected transgene expression in iPS cell experiments.

Beyond the constitutive promoter systems described above, regulated control of gene expression has great significance for stem cell research because of the ability to avoid undesirable effects of constitutive transgene expression after cellular differentiation [15]. Several studies have employed tetracycline (tet)-regulated systems to control transgene expression in both ES cells and iPS cells, thereby enabling the transgene function to be explored in a spatiotemporal manner [16-18]. Each gene delivery and expression system has particular advantages and disadvantages depending on the desired outcome of the experimental design. Here, we briefly 
review representative gene delivery and expression systems from the perspective of their application to iPS cell research.

\subsection{Viral-Based Gene Delivery Systems}

Gene delivery systems are classified into two major classes: virus-based vectors and nonviral vectors (Table 11.1). Viruses are suitable for efficient gene delivery experiments because of their ability to penetrate into the cell nucleus and replicate [19]. Viral vectors have been widely used to deliver foreign genes into the cell nucleus because of their high transduction efficiency and capacity for long-term transgene expression [20]. Ideally, the vector should be nontoxic, minimally immunogenic, and capable of highly efficient penetration and delivery to numerous cell types [21]. The principal viral vectors currently in use include adenovirus, adeno-associated virus (AAV), retrovirus, and lentivirus [22].

\subsubsection{Adenovirus Vectors}

Adenovirus, a 70-100-nm, non-enveloped, double-stranded DNA virus [23], belongs to the family Adenoviridae and is well known to cause respiratory tract infections. Adenoviruses enter mammalian cells via attachment to the Coxsackievirus and adenovirus receptor (CAR) [24]. Adenoviruses rarely integrate with the host genome because their genome is maintained episomally in the cell nucleus. Because of their ability to transduce many cell types, including both dividing and nondividing cells, without genomic integration, adenoviral vectors have been considered as

Table 11.1 Comparison of commonly used viral vectors and piggyBac transposon system

\begin{tabular}{l|l|l|l|l|l}
\hline Vector & Adenovirus & AAV & Retrovirus & Lentivirus & piggyBac \\
\hline $\begin{array}{l}\text { Viral } \\
\text { (non- } \\
\text { enveloped) }\end{array}$ & $\begin{array}{l}\text { Viral } \\
\text { (non-enveloped) }\end{array}$ & $\begin{array}{l}\text { Viral } \\
\text { (enveloped) }\end{array}$ & Viral (enveloped) & $\begin{array}{l}\text { Nonviral } \\
\text { (transposon) }\end{array}$ \\
\hline $\begin{array}{l}\text { Delivered } \\
\text { molecule }\end{array}$ & DNA & DNA & RNA & RNA & DNA \\
\hline $\begin{array}{l}\text { Packaging } \\
\text { capacity [32] }\end{array}$ & $4-5 \mathrm{~kb}$ & $5 \mathrm{~kb}$ & $9-12 \mathrm{~kb}$ & $8 \mathrm{~kb}$ & $9-14 \mathrm{~kb}$ \\
\hline $\begin{array}{l}\text { Genome } \\
\text { integration }\end{array}$ & No & No & Yes & Yes & $\begin{array}{l}\text { Yes } \\
\text { (removable: } \\
\text { cut and paste) }\end{array}$ \\
\hline $\begin{array}{l}\text { Gene } \\
\text { expression }\end{array}$ & Transient & Transient/stable & Stable & Transient/stable & Stable \\
\hline $\begin{array}{l}\text { Applicable } \\
\text { cell types }\end{array}$ & Broad & Broad & $\begin{array}{l}\text { Dividing } \\
\text { cells only }\end{array}$ & Broad & Broad \\
\hline
\end{tabular}


promising delivery systems for gene transduction experiments. However, the transient nature of their transgene expression limits their utility in in vitro research designs, and the toxicity and associated immune responses may hamper their clinical application.

Adenovirus vectors can easily introduce exogenous genes into mouse ES cells [7] and iPS cells [13], and they are also used as effective gene delivery tools for human ES cells and iPS cells [25]. The transient expression mediated by adenovirus vectors is actually an advantage for stem cell research, in that undesirable effects of constitutive transgene expression after cell differentiation can be avoided. Indeed, adenovirally mediated transient expression of Runx2 or PPAR $\gamma$ was shown to efficiently guide mouse iPS cells to differentiate into osteoblasts or adipocytes, respectively [13].

It should be noted that selection of an appropriate constitutive promoter, such as EF1 $\alpha$ and CA promoters, is important for effective adenoviral transgene expression in pluripotent stem cells [26]. When used in adenovirus vectors, the CMV and RSV promoters show weak activity in mouse pluripotent stem cells [7, 13] because they are silenced by DNA methylation $[27,28]$; therefore these promoters may not be the best choice for adenoviral transduction experiments in iPS cell research.

\subsubsection{AAV Vectors}

AAV is a nonpathogenic, nonautonomous single-stranded DNA parvovirus that requires a helper virus such as adenovirus or herpes virus for replication. AAV has many serotypes, and among them, AAV2 is well studied and widely used as a gene delivery vector. Without the helper virus, the AAV genome remains episomal in target cells [29, 30]. Genome integration is observed at a low frequency and at a specific site on chromosome 19 [31]. AAV vectors derived from AAV lack viral coding sequences and rarely cause toxic and immune reactions, and they are thus considered as a promising gene delivery system for clinical use. However, the limited packaging capacity of AAV (approximately $\sim 5 \mathrm{~kb}$ ) is a major limitation of this vector system [32].

One interesting property of AAV is that the inverted terminal repeats (ITRs) of the AAV genome permit AAV vectors to efficiently introduce gene-targeting constructs into homologous chromosomal loci in a cellular genome [33]. This unique property permits gene editing, and efficient gene targeting by AAV vectors has been achieved in human ES cells and iPS cells [34-36]. Damdindorj et al. [37] reported that when used in an AAV vector, the CMV promoter provided stable and robust gene expression in cancer cell lines; however, this promoter does not seem to be preferable for noncancerous cell lines and for the purpose of AAV-based gene targeting. Further studies are needed to identify the most suitable constitutive promoter for the application of AAV vectors to precise genetic manipulation of iPS cells, which could have great scientific and therapeutic potential. 


\subsubsection{Retrovirus Vectors}

Retroviral vectors are among the most commonly used gene delivery systems for target gene transduction. They possess several advantages compared with other viral vectors, such as high-level transgene expression activity in long-term culture of most dividing somatic cells and their large DNA capacity (9-12 kb) [32]. Retroviral vectors reverse-transcribe their single-stranded RNA genome into DNA that is then integrated into target cell genome. According to their genome organization, retroviruses are broadly divided into two categories: simple onco-retroviruses, such as Moloney murine leukemia virus (MLV), and complex retroviruses including lentiviruses, such as human immunodeficiency virus [23]. Onco-retrovirus-based vectors are not capable of gene transfer to nondividing cells because they rely on cell division for transduction.

Importantly, transgene expression by MLV-based vectors is restricted in undifferentiated pluripotent stem cells by de novo DNA methylation [38, 39] and other mechanisms, such as TRIM28-mediated silencing of the promoter element within the MLV long-terminal repeat (LTR) [40, 41]. A retroviral mutant vector, the murine ES-cell virus (MESV), was developed to facilitate target gene expression in ES cells through its ability to escape immediate silencing and initiate proviral expression $[38,42]$; however, the MESV vector is still prone to inactivation during long periods of culture [38]. The self-silencing property of retroviral vectors is advantageous during reprogramming for iPS cell generation because it is necessary for the forced expression of exogenous reprogramming factors to cease once the cell reaches the ES-cell-like state. Indeed, Yamanaka and colleagues first generated iPS cells from mouse and human fibroblasts using MLA-based vectors [2, 3].

However, the self-silencing property of retroviral transduction in pluripotent stem cells would be disadvantageous for molecular studies that require sustained expression of exogenous gene products. In addition, retrovirus vectors have the potential to induce insertional mutagenesis in iPS cells through their random integration into the host genome [43]. These aspects should be carefully considered when designing iPS cell experiments using retroviral vector systems.

\subsubsection{Lentivirus Vectors}

In contrast to onco-retroviruses, lentiviruses are transported to the nucleus of the target cells by active transport but do not require cell division for transduction, which allows them to transduce quiescent and nondividing cells [44]. Lentivirus vectors have an $\sim 8-\mathrm{kb}$ packaging capacity that limits the introduction of many genomic DNA sequences, but most cDNA sequences can be accommodated. Given their advantages, lentiviral vectors have become the predominant vectors for gene transduction in many types of cells and in transgenic animals [45]. 
Similar to other retroviral vectors, lentiviral vectors possess the ability to integrate into the host genome and stably express the delivered target gene. Although insertional mutagenesis by lentiviral vectors is still their major disadvantage, it occurs less frequently for lentiviruses than for onco-retroviruses [46, 47]. To reduce the risk of insertional mutagenesis, non-integrating lentiviral (NIL) vectors, which carry either mutant integrase or mutations in the integrase binding sits, have been developed [48-50]. In this vector system, the lentiviral genome remains episomal in the nucleus, with sustained transgene expression that does not require genome integration $[48,49]$; therefore, it is expected to provide a safe and promising gene delivery system for laboratory and clinical use [51].

One important characteristic of lentivirus vectors is their resistance to silencing during propagation and differentiation of ES cells [52]; as a result, they have become widely used for gene transduction in ES cells [53-56]. Hong et al. [12] demonstrated that when used in a lentiviral vector, the EF1 $\alpha$ promoter drove robust transgene expression in mouse ES cells from undifferentiated status to fully differentiated status during neuronal differentiation, whereas the CMV promoter activated transgene expression only in late stages of differentiation. Norrman et al. [8] reported that the use of ACTB, EF1 $\alpha$, and PGK promoters in lentiviral vectors permitted stable transgene expression in human ES cells, whereas the CMV promoter was less effective and expression was rapidly downregulated within 7 days.

\subsection{Transposon-Based Gene Delivery Systems}

As a nonviral gene delivery method, electroporation has been widely used for exogenous gene expression in ES cells [57]; however, a major drawback of this method is low transfection efficiency. Transposon DNA vectors have been recently used for nonviral gene delivery [58]. The piggyBac transposon, a transposon DNA vector identified from the cabbage looper moth Trichoplusia ni [59], has been reported as a highly efficient tool to insert exogenous genes into mammalian cells [60-62]. The piggyBac transposon system is constituted by two basic elements: a 2,472-bp transposon with 13-bp inverted terminal repeats (ITRs) and a 594 amino acid transposase $[59,63]$.

The piggyBac transposon mediates gene transfer through a cut-and-paste mechanism (Fig. 11.1) [58], where it is inserted into the genomic DNA at TTAA tetranucleotide sites and then integrates with the chromosomal DNA through the activity of the transposase [63]. This system can efficiently deliver DNA fragments sized $9 \mathrm{~kb}$, even up to $14 \mathrm{~kb}$, without significant decreases in transposition efficiency [60]. Another advantage is that the piggyBac transposon can be excised from the original insertion site without leaving any remnant sequence [64]; thus, piggyBac-mediated genetic insertions are reversible. Given its capacity for efficient and reversible gene transfer, the piggyBac transposon system is a promising vector for gene delivery.

The piggyBac transposon system can be used to generate transgene-free iPS cells [65-68], which may thus have increased therapeutic utility. Additionally, the 


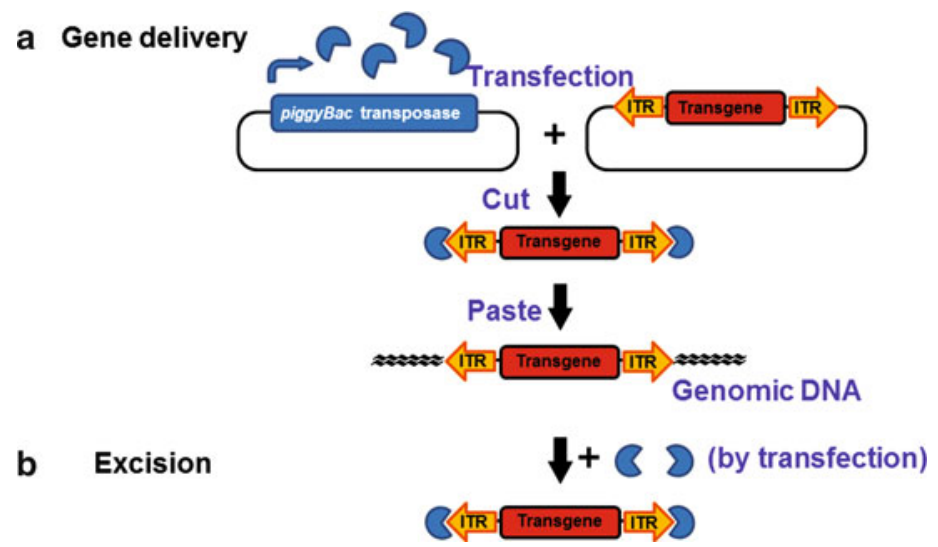

Fig. 11.1 Mechanism of piggyBac transposition. (a) In the transfected cell, transposase is expressed from the piggyBac transposase expression vector, and it then recognizes and binds to the specific inverted terminal repeats (ITRs) of the transgene vector plasmid and cuts the DNA sequence of the transgene from the original sites. Then, the transgene DNA sequence integrates into the genomic DNA of the target cell. (b) For excision, re-expression of transposase by transfection of the piggyBac transposase expression vector leads to cutting of the transgene at the ITRs in the genomic DNA, which results in removal of the inserted transgene from the genomic DNA

piggyBac transposon system has been used for efficient gene delivery to human ES cells, where the insertion can be removed from the ES genome without leaving any insertional mutation as described above $[69,70]$. This system has also been used for gene delivery to human iPS cells [71-73]. In dental research, a piggyBac transposonbased gene expression system has been applied to human deciduous tooth dental pulp cell-derived iPS cells to express EGFP and tdTomato transgenes [74].

\section{4 tet-Controlled Transcriptional Regulation System}

Control of transgene expression is important for preventing potential adverse effects of the continued overexpression of the transgene. tet-regulated gene expression systems are among the most widely used gene regulation systems [75] and consist of two variants: the tet-off and the tet-on systems (Fig. 11.2) [76, 77]. In the tet-off system, when doxycycline, an analog of tet, is absent, the tet transactivators (tTAs) bind to their target element, a tet-operator sequence (tet response element, TRE) that is upstream of a promoter, to drive transgene expression. Conversely, in the presence of doxycycline, the tTAs cannot bind to the TRE; therefore, transgene expression is hindered. The tet-on system was derived from the tet-off system by inducing random mutations in the tTAs [77]. These mutant reverse transactivators (rtTAs) bind to the TRE in the presence of doxycycline to drive transgene expression, and transgene expression does not occur without doxycycline. 
a
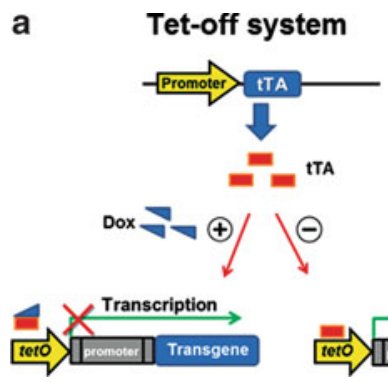

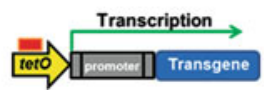

b

Tet-on system

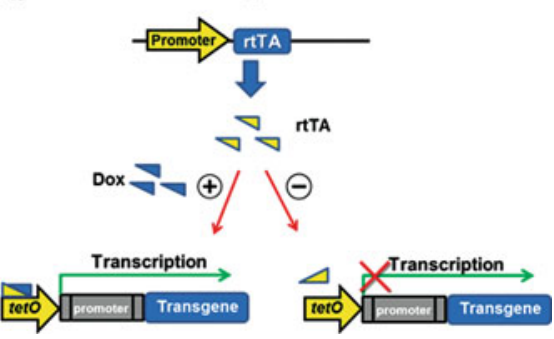

Fig. 11.2 Tetracycline (tet)-controlled transcriptional regulation systems. (a) tet-off system: in the presence of doxycycline (Dox), tet transactivators (tTAs) cannot bind to the tet-operator (tetO) sequence to induce target gene (transgene) expression. In the absence of Dox, tTAs bind to the tetO sequence to drive target gene expression. (b) tet-on system: reverse tet transactivators (rtTAs) bind to the tetO in the presence of Dox to induce transgene expression. In contrast, in the absence of Dox, rtTAs cannot bind to the tetO; thus, transgene expression does not occur

Controlled regulation of transgene expression has great significance for investigating molecular mechanisms of pluripotency and cellular differentiation in stem cells [16], and tet-controlled transcriptional activation systems have thus been applied to pluripotent stem cells $[17,18,78]$. Dox-inducible lentiviral and piggyBac vectors have also been used to direct reprogramming of somatic cells to iPS cells $[66,79]$. This system also permits the regulation of transgene expression in iPS cells to drive their differentiation toward specific cell lineages such as myocytes [71-73].

\subsection{Conclusions}

Because each gene delivery system possesses its own characteristics, researchers should consider the suitability of the system, rather than technical convenience, for a particular iPS cell experiment. The choice of promoter is also important, especially for experiments in iPS cells. Although little systematic information is available regarding the activity of constitutive promoters in undifferentiated iPS cells, the EF1 $\alpha$ and CA promoters, but not the CMV promoter, are expected to be suitable for high levels of stable transgene expression. The piggyBac transposon-based gene delivery system provides several benefits over classic viral and nonviral gene delivery systems. In addition, it can be combined with tet-controlled transcriptional regulation to achieve spatiotemporal control of transgene expression during iPS cell differentiation, which may provide a great impact on iPS cell research. 


\section{References}

1. Egusa H, Sonoyama W, Nishimura M, Atsuta I, Akiyama K. Stem cells in dentistry - part I: stem cell sources. J Prosthodont Res. 2012;56:151-65. doi:10.1016/j.jpor.2012.06.001.

2. Takahashi K, Yamanaka S. Induction of pluripotent stem cells from mouse embryonic and adult fibroblast cultures by defined factors. Cell. 2006;126:663-76. doi:10.1016/j. cell.2006.07.024.

3. Takahashi K, Tanabe K, Ohnuki M, Narita M, Ichisaka T, Tomoda K, et al. Induction of pluripotent stem cells from adult human fibroblasts by defined factors. Cell. 2007;131:861-72. doi:10.1016/j.cell.2007.11.019.

4. Egusa H, Sonoyama W, Nishimura M, Atsuta I, Akiyama K. Stem cells in dentistry - part II: clinical applications. J Prosthodont Res. 2012;56:229-48. doi:10.1016/j.jpor.2012.10.001.

5. Avior Y, Sagi I, Benvenisty N. Pluripotent stem cells in disease modelling and drug discovery. Nat Rev Mol Cell Biol. 2016;17:170-82. doi:10.1038/nrm.2015.27.

6. Kobayashi N, Rivas-Carrillo JD, Soto-Gutierrez A, Fukazawa T, Chen Y, Navarro-Alvarez N, et al. Gene delivery to embryonic stem cells. Birth Defects Res C Embryol Today. 2005;75:10 8. doi:10.1002/bdrc.20031.

7. Kawabata K, Sakurai F, Yamaguchi T, Hayakawa T, Mizuguchi H. Efficient gene transfer into mouse embryonic stem cells with adenovirus vectors. Mol Ther. 2005;12:547-54. doi:10.1016/j.ymthe.2005.04.015.

8. Norrman K, Fischer Y, Bonnamy B, Sand FW, Ravassard P, Semb H. Quantitative comparison of constitutive promoters in human ES cells. PLoS ONE. 2010;5:e12413. doi:10.1371/journal. pone.0012413.

9. Eiges R, Schuldiner M, Drukker M, Yanuka O, Itskovitz-Eldor J, Benvenisty N. Establishment of human embryonic stem cell-transfected clones carrying a marker for undifferentiated cells. Curr Biol. 2001;11:514-8. doi:10.1016/S0960-9822(01)00144-0.

10. Qin JY, Zhang L, Clift KL, Hulur I, Xiang AP, Ren BZ, et al. Systematic comparison of constitutive promoters and the doxycycline-inducible promoter. PLoS One. 2010;5:e10611. doi:10.1371/journal.pone.0010611.

11. Chung SM, Andersson T, Sonntag KC, Bjorklund L, Isacson O, Kim KS. Analysis of different promoter systems for efficient transgene expression in mouse embryonic stem cell lines. Stem Cells. 2002;20:139-45. doi:10.1634/stemcells.20-2-139.

12. Hong S, Hwang DY, Yoon S, Isacson O, Ramezani A, Hawley RG, et al. Functional analysis of various promoters in lentiviral vectors at different stages of in vitro differentiation of mouse embryonic stem cells. Mol Ther. 2007;15:1630-9. doi:10.1038/sj.mt.6300251.

13. Tashiro K, Inamura M, Kawabata K, Sakurai F, Yamanishi K, Hayakawa T, et al. Efficient adipocyte and osteoblast differentiation from mouse induced pluripotent stem cells by adenoviral transduction. Stem Cells. 2009;27:1802-11. doi:10.1002/stem.108.

14. Wen S, Zhang H, Li Y, Wang N, Zhang W, Yang K, et al. Characterization of constitutive promoters for piggyBac transposon-mediated stable transgene expression in mesenchymal stem cells (MSCs). PLoS One. 2014;9:e94397. doi:10.1371/journal.pone.0094397.

15. Wang F, Okawa H, Kamano Y, Niibe K, Kayashima H, Osathanon T, et al. Controlled osteogenic differentiation of mouse mesenchymal stem cells by tetracycline-controlled transcriptional activation of amelogenin. PLoS One. 2015;10:e0145677. doi:10.1371/journal. pone. 0145677 .

16. Masui S, Shimosato D, Toyooka Y, Yagi R, Takahashi K, Niwa H. An efficient system to establish multiple embryonic stem cell lines carrying an inducible expression unit. Nucleic Acids Res. 2005;33:e43. doi:10.1093/nar/gni043.

17. Zhou BY, Ye Z, Chen G, Gao ZP, Zhang YA, Cheng L. Inducible and reversible transgene expression in human stem cells after efficient and stable gene transfer. Stem Cells. 2007;25:77989. doi:10.1634/stemcells.2006-0128. 
18. Qian K, Huang CT, Chen H, Blackbourn LW, Chen Y, Cao J, et al. A simple and efficient system for regulating gene expression in human pluripotent stem cells and derivatives. Stem Cells. 2014;32:1230-8. doi:10.1002/stem.1653.

19. Kay MA, Glorioso JC, Naldini L. Viral vectors for gene therapy: the art of turning infectious agents into vehicles of therapeutics. Nat Med. 2001;7:33-40. doi:10.1038/83324.

20. Boulaiz H, Marchal JA, Prados J, Melguizo C, Aranega A. Non-viral and viral vectors for gene therapy. Cell Mol Biol. 2005;51:3-22.

21. Evans $\mathrm{CH}$, Robbins PD. Potential treatment of osteoarthritis by gene therapy. Rheum Dis Clin N Am. 1999;25:333-44. doi:10.1016/S0889-857x(05)70071-5.

22. Nixon AJ, Goodrich LR, Scimeca MS, Witte TH, Schnabel LV, Watts AE, et al. Gene therapy in musculoskeletal repair. Ann N Y Acad Sci. 2007;1117:310-27. doi:10.1196/annals. 1402.065.

23. Lentz TB, Gray SJ, Samulski RJ. Viral vectors for gene delivery to the central nervous system. Neurobiol Dis. 2012;48:179-88. doi:10.1016/j.nbd.2011.09.014.

24. Bergelson JM, Cunningham JA, Droguett G, Kurt-Jones EA, Krithivas A, Hong JS, et al. Isolation of a common receptor for Coxsackie B viruses and adenoviruses 2 and 5. Science. 1997;275:1320-3. doi:10.1126/science.275.5304.1320.

25. Tashiro K, Kawabata K, Inamura M, Takayama K, Furukawa N, Sakurai F, et al. Adenovirus vector-mediated efficient transduction into human embryonic and induced pluripotent stem cells. Cell Reprogram. 2010;12:501-7. doi:10.1089/cell.2010.0023.

26. Tashiro K. Optimization of adenovirus vectors for transduction in embryonic stem cells and induced pluripotent stem cells. Yakugaku Zasshi. 2011;131:1333-8. doi:10.1248/ yakushi.131.1333.

27. Brooks AR, Harkins RN, Wang P, Qian HS, Liu P, Rubanyi GM. Transcriptional silencing is associated with extensive methylation of the CMV promoter following adenoviral gene delivery to muscle. J Gene Med. 2004;6:395-404. doi:10.1002/jgm.516.

28. Meilinger D, Fellinger K, Bultmann S, Rothbauer U, Bonapace IM, Klinkert WE, et al. Np95 interacts with de novo DNA methyltransferases, Dnmt3a and Dnmt3b, and mediates epigenetic silencing of the viral CMV promoter in embryonic stem cells. EMBO Rep. 2009;10:125964. doi:10.1038/embor.2009.201.

29. Duan D, Sharma P, Yang J, Yue Y, Dudus L, Zhang Y, et al. Circular intermediates of recombinant adeno-associated virus have defined structural characteristics responsible for long-term episomal persistence in muscle tissue. J Virol. 1998;72:8568-77.

30. Schnepp BC, Jensen RL, Chen CL, Johnson PR, Clark KR. Characterization of adenoassociated virus genomes isolated from human tissues. J Virol. 2005;79:14793-803. doi:10.1128/JVI.79.23.14793-14803.2005.

31. McCarty DM, Young Jr SM, Samulski RJ. Integration of adeno-associated virus (AAV) and recombinant AAV vectors. Annu Rev Genet. 2004;38:819-45. doi:10.1146/annurev. genet.37.110801.143717.

32. Ratko TA, Cummings JP, Blebea J, Matuszewski KA. Clinical gene therapy for nonmalignant disease. Am J Med. 2003;115:560-9. doi:10.1016/S0002-9343(03)00447-9.

33. Russell DW, Hirata RK. Human gene targeting by viral vectors. Nat Genet. 1998;18:325-30. doi:10.1038/ng0498-325.

34. Mitsui K, Suzuki K, Aizawa E, Kawase E, Suemori H, Nakatsuji N, et al. Gene targeting in human pluripotent stem cells with adeno-associated virus vectors. Biochem Biophys Res Commun. 2009;388:711-7. doi:10.1016/j.bbrc.2009.08.075.

35. Khan IF, Hirata RK, Wang PR, Li Y, Kho J, Nelson A, et al. Engineering of human pluripotent stem cells by AAV-mediated gene targeting. Mol Ther. 2010;18:1192-9. doi:10.1038/ mt.2010.55.

36. Asuri P, Bartel MA, Vazin T, Jang JH, Wong TB, Schaffer DV. Directed evolution of adenoassociated virus for enhanced gene delivery and gene targeting in human pluripotent stem cells. Mol Ther. 2012;20:329-38. doi:10.1038/mt.2011.255.

37. Damdindorj L, Karnan S, Ota A, Hossain E, Konishi Y, Hosokawa Y, et al. A comparative analysis of constitutive promoters located in adeno-associated viral vectors. PLoS One. 2014;9:e106472. doi:10.1371/journal.pone.0106472. 
38. Cherry SR, Biniszkiewicz D, van Parijs L, Baltimore D, Jaenisch R. Retroviral expression in embryonic stem cells and hematopoietic stem cells. Mol Cell Biol. 2000;20:7419-26. doi:10.1128/MCB.20.20.7419-7426.2000.

39. Minoguchi S, Iba H. Instability of retroviral DNA methylation in embryonic stem cells. Stem Cells. 2008;26:1166-73. doi:10.1634/stemcells.2007-1106.

40. Wolf D, Goff SP. TRIM28 mediates primer binding site-targeted silencing of murine leukemia virus in embryonic cells. Cell. 2007;131:46-57. doi:10.1016/j.cell.2007.07.026.

41. Wolf D, Hug K, Goff SP. TRIM28 mediates primer binding site-targeted silencing of Lys 1,2 tRNA-utilizing retroviruses in embryonic cells. Proc Natl Acad Sci U S A. 2008;105:12521-6. doi:10.1073/pnas.0805540105.

42. Grez M, Akgun E, Hilberg F, Ostertag W. Embryonic stem cell virus, a recombinant murine retrovirus with expression in embryonic stem cells. Proc Natl Acad Sci U S A. 1990;87:92026. doi:10.1073/pnas.87.23.9202.

43. Okita K, Nakagawa M, Hyenjong H, Ichisaka T, Yamanaka S. Generation of mouse induced pluripotent stem cells without viral vectors. Science. 2008;322:949-53. doi:10.1126/ science. 1164270.

44. Lewis PF, Emerman M. Passage through mitosis is required for oncoretroviruses but not for the human immunodeficiency virus. J Virol. 1994;68:510-6.

45. Lois C, Hong EJ, Pease S, Brown EJ, Baltimore D. Germline transmission and tissue-specific expression of transgenes delivered by lentiviral vectors. Science. 2002;295:868-72. doi:10.1126/science.1067081.

46. Hematti P, Hong BK, Ferguson C, Adler R, Hanawa H, Sellers S, et al. Distinct genomic integration of MLV and SIV vectors in primate hematopoietic stem and progenitor cells. PLoS Biol. 2004;2:e423. doi:10.1371/journal.pbio.0020423.

47. Modlich U, Navarro S, Zychlinski D, Maetzig T, Knoess S, Brugman MH, et al. Insertional transformation of hematopoietic cells by self-inactivating lentiviral and gammaretroviral vectors. Mol Ther. 2009;17:1919-28. doi:10.1038/mt.2009.179.

48. Apolonia L, Waddington SN, Fernandes C, Ward NJ, Bouma G, Blundell MP, et al. Stable gene transfer to muscle using non-integrating lentiviral vectors. Mol Ther. 2007;15:1947-54. doi:10.1038/sj.mt.6300281.

49. Philippe S, Sarkis C, Barkats M, Mammeri H, Ladroue C, Petit C, et al. Lentiviral vectors with a defective integrase allow efficient and sustained transgene expression in vitro and in vivo. Proc Natl Acad Sci U S A. 2006;103:17684-9. doi:10.1073/pnas.0606197103.

50. Sarkis C, Philippe S, Mallet J, Serguera C. Non-integrating lentiviral vectors. Curr Gene Ther. 2008;8:430-7. org/10.2174/156652308786848012.

51. Escors D, Breckpot K. Lentiviral vectors in gene therapy: their current status and future potential. Arch Immunol Ther Exp (Warsz). 2010;58:107-19. doi:10.1007/s00005-010-0063-4.

52. Pfeifer A, Ikawa M, Dayn Y, Verma IM. Transgenesis by lentiviral vectors: lack of gene silencing in mammalian embryonic stem cells and preimplantation embryos. Proc Natl Acad Sci U S A. 2002;99:2140-5. doi:10.1073/pnas.251682798.

53. Asano T, Hanazono Y, Ueda Y, Muramatsu S, Kume A, Suemori H, et al. Highly efficient gene transfer into primate embryonic stem cells with a simian lentivirus vector. Mol Ther. 2002;6:162-8. doi:10.1006/mthe.2002.0655.

54. Gropp M, Itsykson P, Singer O, Ben-Hur T, Reinhartz E, Galun E, et al. Stable genetic modification of human embryonic stem cells by lentiviral vectors. Mol Ther. 2003;7:281-7. doi:10.1016/S1525-0016(02)00047-3.

55. Kosaka Y, Kobayashi N, Fukazawa T, Totsugawa T, Maruyama M, Yong C, et al. Lentivirusbased gene delivery in mouse embryonic stem cells. Artif Organs. 2004;28:271-7. doi:10.1111/j.1525-1594.2004.47297.x.

56. Ma Y, Ramezani A, Lewis R, Hawley RG, Thomson JA. High-level sustained transgene expression in human embryonic stem cells using lentiviral vectors. Stem Cells. 2003;21:1117. doi:10.1634/stemcells.21-1-111.

57. Tompers DM, Labosky PA. Electroporation of murine embryonic stem cells: a step-by-step guide. Stem Cells. 2004;22:243-9. doi:10.1634/stemcells.22-3-243. 
58. Woodard LE, Wilson MH. piggyBac-ing models and new therapeutic strategies. Trends Biotechnol. 2015;33:525-33. doi:10.1016/j.tibtech.2015.06.009.

59. Cary LC, Goebel M, Corsaro BG, Wang HG, Rosen E, Fraser MJ. Transposon mutagenesis of baculoviruses: analysis of Trichoplusia ni transposon IFP2 insertions within the FP-locus of nuclear polyhedrosis viruses. Virology. 1989;172:156-69. doi:10.1016/0042-6822(89)90117-7.

60. Ding S, Wu X, Li G, Han M, Zhuang Y, Xu T. Efficient transposition of the piggyBac (PB) transposon in mammalian cells and mice. Cell. 2005;122:473-83. doi:10.1016/j.cell.2005.07.013.

61. Wu SC, Meir YJ, Coates CJ, Handler AM, Pelczar P, Moisyadi S, et al. piggyBac is a flexible and highly active transposon as compared to sleeping beauty, Tol2, and Mos1 in mammalian cells. Proc Natl Acad Sci U S A. 2006;103:15008-13. doi:10.1073/pnas.0606979103.

62. Wilson MH, Coates CJ, George Jr AL. PiggyBac transposon-mediated gene transfer in human cells. Mol Ther. 2007;15:139-45. doi:10.1038/sj.mt.6300028.

63. Fraser MJ, Cary L, Boonvisudhi K, Wang HG. Assay for movement of Lepidopteran transposon IFP2 in insect cells using a baculovirus genome as a target DNA. Virology. 1995;211:397407. doi:10.1006/viro.1995.1422.

64. Mitra R, Fain-Thornton J, Craig NL. piggyBac can bypass DNA synthesis during cut and paste transposition. EMBO J. 2008;27:1097-109. doi:10.1038/emboj.2008.41.

65. Kaji K, Norrby K, Paca A, Mileikovsky M, Mohseni P, Woltjen K. Virus-free induction of pluripotency and subsequent excision of reprogramming factors. Nature. 2009;458:771-5. doi: $10.1038 /$ nature 07864 .

66. Woltjen K, Michael IP, Mohseni P, Desai R, Mileikovsky M, Hamalainen R, et al. piggyBac transposition reprograms fibroblasts to induced pluripotent stem cells. Nature. 2009;458:76670. doi:10.1038/nature07863.

67. Yusa K, Rad R, Takeda J, Bradley A. Generation of transgene-free induced pluripotent mouse stem cells by the piggyBac transposon. Nat Methods. 2009;6:363-9. doi:10.1038/nmeth.1323.

68. Woltjen K, Kim SI, Nagy A. The piggyBac transposon as a platform technology for somatic cell reprogramming studies in mouse. Methods Mol Biol. 2016;1357:1-22. doi:10.1007/7651_2015_274.

69. Lacoste A, Berenshteyn F, Brivanlou AH. An efficient and reversible transposable system for gene delivery and lineage-specific differentiation in human embryonic stem cells. Cell Stem Cell. 2009;5:332-42. doi:10.1016/j.stem.2009.07.011.

70. Chen YT, Furushima K, Hou PS, Ku AT, Deng JM, Jang CW, et al. PiggyBac transposonmediated, reversible gene transfer in human embryonic stem cells. Stem Cells Dev. 2010;19:763-71. doi:10.1089/scd.2009.0118.

71. Tanaka A, Woltjen K, Miyake K, Hotta A, Ikeya M, Yamamoto T, et al. Efficient and reproducible myogenic differentiation from human iPS cells: prospects for modeling Miyoshi Myopathy in vitro. PLoS One. 2013;8:e61540. doi:10.1371/journal.pone.0061540.

72. Kim SI, Oceguera-Yanez F, Sakurai C, Nakagawa M, Yamanaka S, Woltjen K. Inducible transgene expression in human iPS cells using versatile All-in-One piggyBac transposons. Methods Mol Biol. 2016;1357:111-31. doi:10.1007/7651_2015_251.

73. Shoji E, Woltjen K, Sakurai H. Directed myogenic differentiation of human induced pluripotent stem cells. Methods Mol Biol. 2016;1353:89-99. doi:10.1007/7651_2015_257.

74. Inada E, Saitoh I, Watanabe S, Aoki R, Miura H, Ohtsuka M, et al. PiggyBac transposonmediated gene delivery efficiently generates stable transfectants derived from cultured primary human deciduous tooth dental pulp cells (HDDPCs) and HDDPC-derived iPS cells. Int J Oral Sci. 2015;7:144-54. doi:10.1038/ijos.2015.18.

75. Berens C, Hillen W. Gene regulation by tetracyclines. Genet Eng. 2004;26:255-77. doi:10.1007/978-0-306-48573-2_13.

76. Gossen M, Bujard H. Tight control of gene expression in mammalian cells by tetracyclineresponsive promoters. Proc Natl Acad Sci U S A. 1992;89:5547-51.

77. Gossen M, Bujard H. Efficacy of tetracycline-controlled gene expression is influenced by cell type: commentary. Biotechniques. 1995;19:213-6. 
78. Vieyra DS, Goodell MA. Pluripotentiality and conditional transgene regulation in human embryonic stem cells expressing insulated tetracycline-ON transactivator. Stem Cells. 2007;25:2559-66. doi:10.1634/stemcells.2007-0248.

79. Hockemeyer D, Soldner F, Cook EG, Gao Q, Mitalipova M, Jaenisch R. A drug-inducible system for direct reprogramming of human somatic cells to pluripotency. Cell Stem Cell. 2008;3:346-53. doi:10.1016/j.stem.2008.08.014.

Open Access This chapter is distributed under the terms of the Creative Commons Attribution 4.0 International License (http://creativecommons.org/licenses/by/4.0/), which permits use, duplication, adaptation, distribution and reproduction in any medium or format, as long as you give appropriate credit to the original author(s) and the source, provide a link to the Creative Commons license and indicate if changes were made.

The images or other third party material in this chapter are included in the work's Creative Commons license, unless indicated otherwise in the credit line; if such material is not included in the work's Creative Commons license and the respective action is not permitted by statutory regulation, users will need to obtain permission from the license holder to duplicate, adapt or reproduce the material. 